\title{
Language and Aspiration of the Students on Global Outlook: a Review Based on Malaysia Education Development Plan (2013- 2025)
}

\author{
Sharipah Nur Mursalina Syed Azmy (Corresponding author) \\ Department of Moden Languages and Communication, Faculty of Languages and Communication, University Sultan Zainal Abidin, \\ Gong Badak Campus, 213000 Kuala Terengganu, Terengganu, Malaysia \\ E-mail: shnurmursalina@unisza.edu.my \\ Nor Hafizah Abdullah \\ Department of Moden Languages and Communication, Faculty of Languages and Communication, \\ University Sultan Zainal Abidin, Gong Badak Campus, 213000 Kuala Terengganu, Terengganu, Malaysia \\ E-mail: hafizahabdullah@unisza.edu.my \\ Suffian hadi Ayub \\ DCLA, Faculty of Arts, No. 2, Jalan Universiti, Bandar Sunway, 47500 Selangor darul Ehsan, Malaysia \\ E-mail: suffianay@sunway.edu.my
}

Received: 18-06-2016

Published: 01-11-2016
Accepted: 25-08-2016

doi:10.7575/aiac.ijalel.v.5n.6p.240
Advance Access Published: September 2016

URL: http://dx.doi.org/10.7575/aiac.ijalel.v.5n.6p.240

\begin{abstract}
The Malaysia Education Development Plan (2013 - 2025) (pre-school to post-secondary education) was launched by the Ministry of Education on October 2011. This plan aimed at transforming the national education system holistically and was based upon the international standard to instil the national aspiration and to prepare the students with sufficient competitive edge when upon completion of their study. This paper reviewed the six aspirations outlined in the Malaysia Education Development Plan which encompassed knowledge, thinking skills, leadership skills, bilingual skills, ethics and spirituality, and national identity. Each of these elements provide a holistic approach in ensuring the students are well equipped not only with knowledge and soft skills, but most instrumentally they are able to engulf the spirit of national identity. This is highly important in today's world as without it, the country would not be able to move forward with its Vision 2020 when the people are not united and prepared to strive for excellence. This paper discovered that the six aspirations listed in the Malaysia Education Development Plan are embedded strategically in each of the thrust in developing the new generation of students.
\end{abstract}

Keywords: Malaysia Education Development Plan, knowledge, development, national identity, students, aspirations

\section{Introduction}

Education involves knowledge, skills and values that are delivered and developed continuously from one person to another, from one culture to another and from one civilization to another. Therefore, education among citizens plays an important role in economic growth and development of a country. The success of a country tremendously depends on knowledge, skills and competency possess by the citizens. Education is also fundamental in nation building and strengthening the unity apart from increasing the citizen's standard of living and becoming a successful society (Malaysia Education Development Plan (2013- 2025)). Furthermore, it will contribute to enhance the country's economic development.

However, the Malaysian achievement in an internal exam, the Program for International Student Assessment (PISA) in 2009 was very distressing because Malaysia is ranked in the one third lowest positions compared to other developing countries. Far from it, Thailand also surpassed Malaysia. The situation is very distressful because Malaysia allocated and spent a huge budget, much higher from the countries that surpassed it in the PISA result. Due to the current global economic that demands the importance of education, the government needs to make the transformation to improve the Malaysian education system level and prepare the younger generation for the $21^{\text {st }}$ century challenges.

The National Education Philosophy aspires to enhance individual's potential as a whole and integrated to establish a balance and harmony human being intellectually, spiritually, emotionally and physically based on the belief and submissive to god. This effort is to establish the Malaysian citizen who is knowledgeable, competence, morally upright, responsible and able to achieve self-potential and contribute to the family, society and country's harmony and prosperity. In line with this aspiration, the Ministry of Education Malaysia (MOE) has outlined six aspirations that need to be possessed by every student to face the globalization and current challenges, namely: 
- Knowledge

- Thinking skill

- Leadership skill

- Bilingual skill

- Ethics and spirituality

- National identity

\section{Knowledge}

Knowledge means knowing or whatever that is known (Kamus Dewan, 2005,1571). Therefore, every child needs to fully master the knowledge delivered at the early stage of education. The early stage education is very important to determine the success of children in the following stage. If a child possesses high skills from the early stage of education, the opportunity to succeed will increase. Therefore, in an effort to provide the best education to students, MOE had taken the initiative by launching Linus programme under National Key Results Area (Bidang Keberhasilan Utama Nasional (NKRA) Pendidikan).

Linus is a rehabilitation programme formulated to enable students to acquire basic literacy and numerical skills (mastering $3 \mathrm{M}$ - reading, writing and calculating) during the first level in primary school. Based on the Malaysian Education Development Plan 2013-2015, at the basic level, children need to fully master literacy and numerical skills (Malaysian Education Blueprint Executive Summary, 2013-2015,16). Literacy refers to students' ability to read, write and understand words and sentences in Malay. Meanwhile, numerate is the ability to perform basic mathematics operation and understanding simple mathematics idea. Later, students will be able to apply the knowledge in the daily learning and communication.

Students who are not able to master the $3 \mathrm{M}$ will contribute to the dropout rate in schools, besides increasing disciplinary problems. This will also lead to the occurrence of cumulative academic failure and it is difficult to improve this matter at the higher level (Bidang Keberhasilan Utama Nasional (NKRA) Pendidikan). Realizing the fact that there are still many students who could not master the $3 \mathrm{M}$, emphasis is given to the year one to year three students according to their own standard. Indirectly, it will uplift the education level in Malaysia and is able to produce manpower that is able to compete from the early education stage.

This matter, however, needs to be enhanced to the secondary level education and higher learning institutions. Every student needs to master the core subject like Mathematics and Science and comprehensively learn general knowledge on Malaysia, Asia and the world from the historical, human and geographical aspects. Students are also encouraged to expand their knowledge and skills in other areas such as arts, music and sports. To realize the Malaysian education aspiration, a shift in the teaching profession is also very much needed. Such knowledge and skills development is crucial for improving the competitiveness in preparing them to be dynamic and versatile that the industry needs. This will also assist in realizing the Malaysian education aspiration.

Transforming teaching profession is very important so that appointed teachers will have suitable credibility to educate students in all aspects. The government has taken the initiative by transforming teaching profession to become the profession of a choice so that appointed teachers are more suitable according to the standard being set. This will give a positive effect to the education field because intake of suitable teachers will give a great impact to the students' knowledge. Following this, students can gain knowledge with a broader perspectives with the tutelage of the instructors who are expert in various fields. The disseminated knowledge too will be more secure and the students will become the valuable human capital for the nation. Moreover, it could also potentially increase the credibility of would-be leaders in the future and be able to compete at the global level.

\section{Thinking Skills}

Ministry of Education (MOE), in the establishment of National Education Development Plan 2013 - 2025, has introduced the thinking skills as one of the six pillars needed by the students in order to compete in the globalized world. It is deemed as significant because these are the generations that will continue to propel Malaysia towards an advanced nation by the year 2020. As a matter of fact, to further elucidate the importance of thinking skills among students, it has been embedded as one of strategic thrust in Malaysia education through the Kurikulum Bersepadu Sekolah Menengah (KBSM).

Meanwhile, the thinking skills in the classroom too, play an important role as it ensure the students' comprehension should not limit to understanding the subject matter, but most essentially having the ability to adopt it in the daily life. De Bono (1976) relates thinking skills and lateral thinking through understanding its function whereby it does not limit to solving a problem, but the ability to think and see something from different perspectives. Therefore, it is imperative to note that thinking skills in the context is a foundation to prepare the students for the outside world.

Abdul Rahim (1999), opined that when discussing about thinking skills among students and its preparation in developing the country, there must be a structured plan to establish a thinking society which is the very essence of civil society in any civilization. Saedah Siraj (1994) stated that critical and creative thinking need to be expanded among students so that they will be able to solve problem and see life in a more positive way. This means that thinking skills is a process which is nurtured carefully so that the students when they graduate will become a part of society that can contribute to the nation 
wholeheartedly.

The success of a student does not rely on the set of skills in memorizing the subjects matter as it this will only become a part of skill in the examination. Instead, the crucial part is when the knowledge can be applied in different context of life whereby thinking skills are proven to be at played. John Arul Philips (1997) stressed that a huge part of knowledge learnt at school will become obsolete if it is not applied either in personal or professional life. What will remain and fully utilized in lifetime is the thinking skills that was learnt upon which the knowledge is obtained.

\section{Leadership Skills}

Leadership skills in the globalization era covers the aspect of administering, supervising and most significantly is the succession plan to ensure continuity in the leadership. Fiedler (1967) defined leadership as interpersonal relationships where power and influence are not equally distributed which result in certain individual exerts control over another. This definition, stress upon the importance of having good leadership skills to ascertain justice and impartiality when exercising one's power.

In this dynamic and constant changing environment, leadership skills are highly needed as this will put forth confidence even though the challenges ahead are difficult. Norani Mohd Noor \& Sazalie Sahimin (2010) found out that students perceived leader as someone who gives a good idea, think innovatively and rely on individual's strength. This exemplifies that students are indeed require a nurturing in the leadership skills in school and its application could be observed when they are in working sector.

In the context of educating leadership skills at school, it could be implemented either in the curriculum or co-curriculum activities and it could also be imparted formally or informally. This has actually become a part of soft skills that the students need to accomplish. Further to that, Mohd Salleh et. al. (2010) stated that soft skills is an attribute to ensure that particular individual successfully functions well in the society, and leadership skills is one of the soft skills requirements. Clearly, when discussing education and leadership skills, it has shown that the government of Malaysia is very supportive on its implementation. This can be seen when the continuity of leadership skills is further empower at the institutions of higher learning as well.

\section{Bilingual Skill}

In Malaysia, the country's education policy assumed that students completed schools with the ability in at least two languages i.e. Malay (the medium language) and English (the second language in the education system). Besides that, there are majority of students with mother tongue besides Malay, such as Chinese, Tamil, Kadazan, Iban and others. Further to this foreign languages are also introduced in schools such as Arab, Japanese, French and other languages (Nik Safiah Karim, 1994). These are among of the key characteristic needed by every student to enable them to compete globally. With Malay language at the forefront as the national and unity language and English as an international communication language, students should be able to use both languages in the working environment.

Historically, between the period of 1957 to 1967, Malay and English are used as official languages. The school system in Malaysia has 4 stream; Malay, English, Chinese and Tamil. English is the second most important language in the country. English initially was used in the English medium schools as well as schools of Malay, Chinese and Tamil since its inception in the pre-independence British period. The British government confirmed the existence of four separate education system (Abdullah Hassan, 1999). In the shortest period of ten years, six reports of education was established to explore the educational system, all of which suggests bilingualism with English language education taking a leading role. Malaya Constitution also makes the Malay language as the national language. Malay language to be used in addition to English for over ten years. After that, the Malay language replace English and became the sole official language. Malay is the sole medium of instruction in schools (Abdullah Hassan, 1999).

The Malaysian National Education Policy 1966, mentioned that English is the second most important language which means that the second after the national language and it should be taught as effective second language at schools in Malaysia (Asmah, 1987). This is to ensure the vested interests of English while championing the Malay language as the national language. However, economic growth factors also play an important role in the development of bilingual education, especially English language requirements in sectors involving economic activities such as engineering, industrial, commercial and others. Asiah (1999) mentioned that English is given a new role as the second language. Although this role is limited as compared to Malay, but is very important in terms of trades and international communication.

Despite that, many students who have completed their studies are only able to master good Malay but their English mastery remain very low. Since 2006, the poor mastery of the English language among new graduates is alarming and has been identified as one of the five issues faced by the employers in Malaysia (Malaysia Education Blueprint Executive Summary, 2013-2015, 23). Therefore, to increase the efficiency level of both languages, MOE implemented few transformation shifts to ensure every student is able to master Malay and English language as well as encouraging them to take up additional languages.

Through the education transformation plan, the MOE has implemented the Malaysian language curriculum for schools with intensive remedial support for students in need. In 2011, a new curriculum has been developed specifically for national-type schools where students do not use Bahasa Malaysia as the language of instruction. This curriculum provided learning standard requirements with the level 1 and focusing to achieve standard of proficiency similar to national schools and the appropriate assessment will be conducted at year 6 . Nevertheless, to achieve the required standards, the initiative 
of the parents are also needed as it is the option of the parents to send their children for remedial classes, if necessary.

MOE has also expanded the Linus programme so that it covers English language literacy. This means students will be observed at two literacy levels for two languages, namely, Malay and English language. To ensure their progress is at expected levels, students will be screened twice a year. Students who fall behind will be required to attend rehabilitation classes and teachers will receive special guidance from mentor teachers at the district level.

Teachers' skills also need enhancement especially English teachers so that every student is able to follow the lesson from the skillful teachers at par international standard. In lieu, MOE will ensure all English language teachers participate in the Cambridge Placement Test (CPI) for two years period. As for those who do not achieve the standard, they will be required to undergo intensive training. Other than that, to enhance the bilingual skill, every student is encouraged to learn additional language as this is paramount in assisting the students in the global work force.

To ensure that the manpower produced is able to compete globally, bilingual skill is very important and must be exposed to students as it will also assist them in building confidence to communicate especially in the challenging working environment.

\section{Ethics \& Spirituality}

Schools need to strive to establish a strong common value based on a set of principle namely, Spirituality; to ensure students possess strong religious adherence and practice them as a life fundamental, and possess high moral grounding. Besides that, Integrity; ensuring students are guided so that they have courage, discipline and will to do the right thing, and Civic Responsibility; students are guided towards positive attitude and act for the nation's benefit, care for others as well as the environment. Each and every child will have a strong moral fundamental to overcome various life challenges and help them make decisions accurately and with courage based on three sacred values in ethics, namely, spirituality, humanity and citizenship elements (Mior Khairul Azrin, 2011). The other three important elements of ethics are:

\subsection{Kindness}

The spiritual element in the sacred value is associated with compassion and thoughtfulness traits. The negative traits that often occur in human being are spiteful and vengeful. Whereas, the compassion trait is divinity or sacred. The humanity element is the generous trait. The generous human being will be loved and respected by others. The nationality element can be seen in the traits of mutual understanding. Looking at the country's various ethnic groups, the mutual understanding between the people of other races is very important to avoid conflicts.

\subsection{Fairness}

There is a spiritual element in the value when a leader acts fairly to his/her subordinates. The fair leader is the character of piety, which means he/she fears of Allah s.w.t. There is also element of humanity in this value, which is when people in power do not simply use his/her power against the weak. The element of nationality also is available in the fair government when discharging their responsibilities.

\subsection{Honesty}

An honest person is always heartfelt and sincere in his/her actions. He/She is aware that although people do not see it, but the fact that Allah s.w.t. is always watching his/her every move. Therein lies the spiritual trait in this value. Honesty in a relationship with another person reflects the purity of heart, which is the trait of distinguished humanity. A good and an honest person plays an important role as citizens. This is because there will be no people who cheats the government to avoid paying taxes, for instance is the income tax (Mior Khairul Azrin, 2011).

Therefore, to achieve a strong national unity, the whole society needs to collaborate with the government's effort through new policies and plans. A perfect education quality and a harmonious society relationship become the fundamental success that will make a country develop and able to realize the vision.

\section{National Identity}

The sixth student's aspiration in the Educational Development Plan (EDP) is related to the effort of building national identity among students. National identity or national ideology. This refers to the beliefs and ideologies of a nation that form its collective identity whereby the corresponding languages of those identities are being promoted through language policy (Albury \& Khin, 2016). Among others, the aspiration is to have students with undivided feelings and holding strongly to the principal of the National Commandment and always prioritizing unity. Kamus Dewan (2005) defines unity as a combination, investment adaptation, suitability and unity, i.e. combining to become one, unanimous and many others. Schools need to play the role as fertile nurseries to enhance the spirit of patriotism among students regardless of race, ethnic, belief, social economic status or location. Meanwhile, students should be proud as children, understanding and accepting differences, respecting others and be prepared to live in multicultural variety. Each and every children irrespective of religion, ethnic or social economic status should feel proud to be known as a child. In this context, Malay language is significant as the unity language as it becomes the symbol of unity of voice that is used as a communication tool.

In the effort to strengthen the National language, teachers' role is very important because through education, students need to be realized on the importance of Malay language as the national, official, unity and communication languages (Amir Hassan, 2010). The Malay language has long been established as a medium language in schools, colleges, polytechnics and universities. The effectiveness trait of the Malay language is also able to give accurate and effective meaning without arising confusion as a medium language. Besides that, the responsibility of educational institution 
leaders, lecturers and teachers is to inculcate the spirit of loving the Malay language to younger generation so that they can speak the language fluently, respect and be proud of the Malay language as a citizen's identity. The Malay language does not only necessarily belong to the Malays but it belongs to all of us.

It is very clear that the role of Malay language in shaping citizens' sense of identity has great challenges. Hence, the national aspiration and mission in shaping a nation, namely uniting the people and shaping the common sense of identity among its citizen will not be achieved if the citizen does not manifest the strong spirit to elevate the dignity of the Malay language as the national language that should be the pride of our country. At the same time, a global citizen development needs to be balanced with a strong national identity development. Clearly, every party, written and unwritten, feels the need to retain their identities (Amir Hasan, 2010).

\section{Conclusion}

It is clear that the Malaysian Development Education Plan will continuously carry the aspiration of the National Education Philosophy for a balanced education as a fundamental aspiration for every student. The fundamental aspiration outlined has played a role in creating manpower with intellectual and personality suitable with the current Malaysian developing situation. Malaysian who are knowledgeable, competence, have upright moral values, responsible and competent will make Malaysia a visionary developed country. The outlined aspiration will also create generation that has the potential to compete globally in line with the current demand. However, the fundamental implementation of this plan should be in line with the Malaysian Constitution, which emphasizes that Malay as the national language. Therefore, MOE should give more emphasis to Malay, the unity and unification language.

Further to this, these six aspirations should also be seen as founding principles for the government upon making any more changes to the nation's education blueprint. This means that any proposal put forth must meet these six aspirations prior to being submitted for consideration. It is in these aspirations that the human capital could be nurtured and its growth in capacity building could provide sustainable resource for the nation. In transforming the nation, its sole effort should first focus at its young generation for they are the asset for the country and its economic growth.

\section{References}

Abd Rahim Abd Rashid. (1999). Kemahiran Berfikir Merentasi Kurikulum. Shah Alam: Fajar Bakti Sdn. Bhd.

Abdullah Hassan. (1999). Perancangan Bahasa di Asia Tenggara. 66-82. Kuala Lumpur: Dewan Bahasa dan Pustaka.

Abdullah Hassan. (1999). Asimilasi bahasa: Suatu tinjauan terhadap dasar pendidikan bahasa dan penerimaan bahasa Melayu di Malaysia Barat. Dlm. Terj. Abdullah Hassan. Perancangan bahasa di Asia Tenggara. 130-171. Kuala Lumpur: Dewan Bahasa dan Pustaka.

Amir Hasan Dawi. (2010). Kepentingan Identiti dan Perjuangan Etnik dalam Masyarakat Malaysia. Persidangan Antarabangsa Minoriti dan Majoriti: Bahasa, Budaya dan Identiti.

Asiah Abu Samah. (1999). Perancangan dasar pendidikan bahasa di Malaysia: Keprihatinan Terhadap Perpaduan. Realiti dan Kerasionalan.

Albury, N. J., \& Khin, K. A. (2016). Malaysia's National Language Policy In International Theoretical Context. Jurnal of Nusantara Studies 1(1) 71-84.

Asmah Hj. Omar. (1999). Nasionisme dan Eksoglosia: Kes Bahasa Inggeris Di Malaysia. Dlm. Terj. Abdullah Hassan. Perancangan bahasa di Asia Tenggara. 83- 108. Kuala Lumpur: Dewan Bahasa dan Pustaka.

De Bono, Edward. (1976). Teaching Thinking. London: Maurice Temple Smith.

John Arul Phillips. (1997). Pengajaran Kemahiran Berfikir: Teori Dan Amalan. Utusan Publications.

Kamus Dewan (Edisi Empat). (2005). Kuala Lumpur: Dewan Bahasa dan Pustaka.

Mior Khairul Azrin Bin Mior Jamaluddin. (2011). Sistem Pendidikan di Malaysia: Dasar, Cabaran dan Perlaksanaan Ke Arah Perpaduan Nasional. SosioHumanika 4(1).

Nik Safiah Karim. (1994). Unsur Dwibahasa dalam Masyarakat Malaysia. Pelita Bahasa, Mac: 28 - 29.

Norani Mohd Noor \& Sazalie Sahimin. (2010.) Penerapan Kemahiran Generik Dalam Proses Pengajaran Dan Pembelajaran Di $\quad$ Kolej $\quad$ Yayasan Sabah. Http://Eprints.Utm.My/10527/1/Penerapan_Kemahiran_Generik_Dalam_Proses_Pengajaran_Dan.Pdf tarikh: 26 Jun 2014.

Saedah Siraj \& Knolle, L. M. (1994). A Comparative Analysis Of Preference And Performance Measurements Of Cerebral Bilateral Asymmetry. Jurnal Pendidikan, Journal of Educational Research, 16, 17-25. 